\title{
A Viewpoint on Intervention with Inheritance of Traditional Arts and Crafts by Vocational Teaching of Arts and Crafts
}

\author{
Ning Wang \\ Art School \\ Guangdong Industry Technical College, \\ Guangzhou, China \\ e-mail: 103817165@qq.com
}

\begin{abstract}
On the basis of analyzing that the core for current inheritance crisis of Chinese traditional arts and crafts is that the young group lacks of a sympathy for cultural aesthetics carried in traditional crafts, this paper presents the viewpoint that intervention with inheritance of traditional arts and crafts by vocational teaching of arts and crafts should be based on the principle of "taking dissemination of traditional craftsmanship as the guidance, inheritance of traditional aesthetic spirit as the core and establishment of balance point for traditional formal language, modern design idea and aesthetics of traditional craftsmanship as the goal".
\end{abstract}

Keywords-vocational education; arts and crafts; teaching; intervention; tradition; inheritance

\section{INTRODUCTION}

The development history of arts and crafts is just like a life mechanism. Social attention is the root for its life extension, inheritance of cultural aesthetics is the extension of its gene and aesthetic perception changing in different periods is the power driving it forward. During the development of traditional arts and crafts, new craft forms always appear, expand and develop continuously, while some forms unsuitable for the social environment will disappear and transform, or their content, form and use will change. During this process, as long as the vigor of life will not decline, the cultural inheritance of arts and crafts can continue always.

\section{CURRENT INHERITANCE CRISIS OF TRADITIONAL ARTS AND CRAFTS}

In an archaeological view, in the region of Northeast Asia, the privative society started the Neolithic Times ten thousand years and was observed with behavior of real arts and crafts. From the Neolithic Times to the modern times, the ancient people living in the region for generations have been continuously created various and exquisite works of arts and crafts, which has historically won for China such honors as "Country of Silk", "Country of Ceramics" and "Country of Lacquers" in different periods. Yet, regretfully, with the rapid development of human science and technology civilization, acceleration of living pace and gradual change of traditional humane customs, especially since the western civilization brought changes to the oriental cultural value and aesthetic temperament and interest with its powerful science and technology over the last 150 years, the gap is being rapidly widened between the contemporary Chinese arts and crafts and the modern Chinese people.

Currently, the overall development of Chinese arts and crafts industry is not so optimistic. At present, the industry of arts and crafts in China is obviously behind Japan, South Korea and other surrounding countries and regions in the Northeast Asia and even its development is also in a state of slow stagnation. In terms of theoretical studies, by consulting various books on arts and crafts, the author observes that books for appreciation of works are in the majority, but technical books are short for introduction of fabrication methods and popular books are short for craftsmanship. In addition, in-depth systematic theoretical studies are also short for traditional arts and crafts. In a macro view of the industry, as for such problems as deficient innovation in the industry of traditional arts and crafts and difficult inheritance of skills, the governmental authorities have also published relevant preferential and protective policies and the industry and enterprises thereof have also continuously and positively adjusted the survival conditions, but these can only relieved the current dilemma at a policy and technical level, or postpone the gradual decay of the whole industry of arts and crafts in China in terms of time, without resolving fundamentally the crisis for the development vigor of the whole industry to fade.

Man cares for beauty and social groups in different periods would create and select proper visual formal language according to the rules of beauty. Therefore, with new forms of arts and crafts continuously emerging, developing and expanding, some old forms may disappear and transform and the content, form and use will also change. During this process, many varieties and skills of traditional arts and crafts are all close to being lost or extinct, but these are not so terrible. Just like the metabolism of body, they are still within the controllable range for the development and evolution of arts and crafts. However, the change and deficiency in social attention to the whole industry of arts and crafts can, in decades, affect and even cut off the cultural aesthetic inheritance lasting 
in arts and crafts. Therefore, what is critical for persuading the crisis of traditional arts and crafts is to inspire the social attention and it is essential to guide the young groups to have a sympathy for cultural aesthetics carried in the traditional arts and crafts, especially the acceptance of the young "university student" groups, as the subject group that will create values for the society in the coming 10 or 30 years.

\section{OVERVIEW OF VOCATIONAL ARTS AND CRAFTS}

At present, in China, the higher vocational education is in the category of higher education at the level of junior college without any academic degree. Being different from the ordinary higher education, its major setup is oriented for employment of students. Its teaching stresses on cultivation of vocational skills. Its objects for cultivation are senior application-type skilled talents for the purpose of promoting the technical level of employees at the front of production. As part of higher education in China, the vocational education shares more than half of the higher education by quantity of cultivating students. It is meant to meet the needs for the rapid development of manufacturing industry in China as well as accompanied by the large-scale recruitment expansion due to the recent change in the idea of running the higher education in China "elite education and public education".

In China, the teaching of vocational arts and crafts was originally separated from the traditional pure artistic education in the form of applied artistic education. Later, with the social demand being classified, such design majors as industrial design, planar design, environmental design and costume design were successively separated from the applied artistic education. Yet, as the industry of arts and crafts has gradually decayed in recent years, the teaching direction for the major of arts and crafts has also changed from teaching one special technique of arts and crafts (such as lacquer, ceramics, wood carving and dyeing and weaving) to cultivating the accomplishment of comprehensive artistic design. Its teaching advocates for cultural expression as the core and technical express as media, while its works are mostly represented in the mode exhibiting the craftworks. Thus, in addition to the traditional arts and crafts, students of arts and crafts are also active in such professional areas as industrial design, planar design, environmental design and costume design.

\section{A VIEWPOINT ON THE INTERVENTION WITH THE INHERITANCE OF TRADITIONAL ARTS AND CRAFTS BY VOCATIONAL TEACHING OF ARTS AND CRAFTS}

\section{A. Strength of intervention}

Firstly, in view of the education of arts and crafts, the industrial knowledge, formal language and technical skills of traditional arts and crafts are brought into the course practice to expand the connotation for the cultural aesthetic cultivation of arts and crafts teaching and to provide powerful support to students in developing formal language in their innovation of arts and crafts design. Secondly, as for the industry of traditional arts and crafts, since the base of students at the vocational level is huge, the employment for students of arts and crafts covers a wide professional range, the exchange between the colleges and the industry of traditional arts and crafts can create more properly topics to trigger the attention of social public, especially of the "university student group" that are the future social value creators, so as to consolidate the social grassroots for the sustainable development of traditional arts and crafts.

The interaction between the two not only can gradually guide the young group to form a sympathy for the cultural aesthetics carried in traditional arts and crafts, but also can promote the practitioners of traditional arts and crafts to form the innovative consciousness, thus playing a role in leading the modern transformation and promotion of traditional arts and crafts. Furthermore, the vocational graduates have an appropriate educational level, mature thought and commonly stable psychology for employment. With the contact increasing with traditional arts and crafts, it will be also easy to select from them the proper candidate for skillful inheritance of traditional arts and crafts.

\section{B. Principle of intervention}

In China, the talent cultivation of vocational education is relatively huge by quantity for the fundamental purpose of cultivating the skilled talents to promote their occupational level. However, since the traditional arts and crafts have various majors and commonly featured for long period of skill learning, slow effect and less demand for single-major, the intervention with the inheritance of traditional arts and crafts by vocational arts and crafts teaching cannot be carried out in mode of "pure skill learning" or "setting up the major for one skill of traditional arts and crafts". The combination of the two should be based on the principle of "taking dissemination of traditional craftsmanship as the guidance, inheritance of traditional aesthetic spirit as the core and establishment of balance point for traditional formal language, modern design idea and aesthetics of traditional craftsmanship as the goal". Its inheritance focuses on guiding the consciousness and sympathy of students for traditional cultural aesthetics and its development stresses on the angle for the modern design idea to intervene with innovation in traditional arts and crafts.

\section{Breakthrough point for intervention}

The breakthrough point for intervention with the inheritance of traditional arts and crafts by vocational teaching of arts and crafts can be two directions: firstly, introduce the traditional arts and crafts, introduce Lingnan traditional arts and crafts into society from campus through interaction in such forms as arts and crafts masters' theoretical teaching, lecture and exhibition, narrow the gap between students and traditional arts and crafts, and intensify their perceptional knowledge of traditional skill aesthetics and expand the influence of traditional arts and crafts so as to obtain an effect of development cultivation base for inheritance of traditional crafts and enriching the connotation of inheritance. During such process, adequate space can be given to student for innovation and the classroom of arts and crafts can be changed to the experimental field of simulating the awareness of traditional arts and crafts enterprises for innovation by teaching the design practice of arts and crafts, applying experimental teaching means and making use of the young people's sensitivity for popularity and fashion. 
Secondly, approach positively the enterprises of traditional arts and crafts. During the project cooperation between schools and enterprises, the intelligent resources of colleges not only can, through implantation of modern design idea, help to find, for products of traditional arts and crafts, the formal language meeting the modern aesthetic concept and means for unfolding skill aesthetics, but also can optimize the existing operation mode of traditional crafts by changing packaging, optimizing propaganda mode and other design planning ideas so as to improve the survival conditions for the enterprises of traditional arts and crafts and thus play a role in promoting the development of arts and craft.

\section{CONCLUSIONS}

Intervention with inheritance of traditional arts and crafts by vocational teaching of arts and crafts should be based on the principle of "taking dissemination of traditional craftsmanship as the guidance, inheritance of traditional aesthetic spirit as the core and establishment of balance point for traditional formal language, modern design idea and aesthetics of traditional craftsmanship as the goal". When the traditional arts and crafts traditional arts and crafts become social through colleges and skills are integrated with modern design ideas, with the approaches for in heritance of skills expanding in the industry of traditional arts and crafts, the dissemination of traditional arts and crafts cultural aesthetics expanding, and the skill aesthetics of traditional arts and crafts becoming popular, it is reasonable to believe that the Chinese traditional crafts can be really inherited and developed.

\section{REFERENCES}

[1] QIAN Chuxi. Teaching Theory and Method for Arts [M]. Beijing. Higher Education Press, 2006

[2] J. Clerk Maxwell, A Treatise on Electricity and Magnetism, 3rd ed., vol. 2. Oxford: Clarendon, 1892, pp.68-73.

[3] WANG Wenzhang. An Introduction to Intangible Cultural Heritage [M]. Beijing: Culture and Art Publishing House. 2006

[4] QIAO Xiaoguang. Local Spirit: Collection of Studies on Intangible Cultural Heritage and Folk Arts [M]. Nanchang. Jiangxi Arts Press. 2008

[5] SUN Jianjun. Chinese Folk Arts [M]. Shanghai. Shanghai Pictorial Press. 2006

[6] LIU Xicheng. Intangible Cultural Heritage: Theory and Practice [M]. Beijing. Academy Press. 2009 